\title{
ENDOSCOPIC MANAGEMENT OF SINONASAL TUMORS
}

\author{
By \\ Yasser W. Khafagy, MD \\ From \\ Associate Professor of Otolaryngology, Faculty of Medicine, \\ Mansoura University Mansoura, Egypt.
}

\section{ABSTRACT}

Objective : To evaluate the outcome of the endoscopic approach for sinonasal neoplasms

Study design : Prospective study

Patients and Methods : Fifty one patients with sinonasal tumors were treated by the author in the period from 1997 to 2004. Tumors were either resected exclusively via an endoscopic approach (35 cases) or in association with other approaches (16 cases). This study included patients with inverted papilloma (23), angiofibroma (13), vascular lesions (7), fibroosseous lesion (2), osteoma (2), hemangiopericytoma (2), odontogenic nasal tumor (1), and salivary gland tumor (1).

Results : The mean follow up period was 32 months. Tumor recurrence occurred in 3 cases (2 inverted papil- lomas and 1 angiofibroma). No major complications were encountered.

Conclusion: Endoscopic and endoscopic assisted resection of sinonasal tumors is effective. The endoscopic approach can be employed together with non-endoscopic approach whenever there is no possibility of complete visualization and consequent successful resection of the tumor.

Key words : sinonasal tumors, endoscopic surgery

\section{INTRODUCTION}

The endoscopic endonasal approach has been successfully employed in the last decade for the resection of sinonasal tumors such as inverted papilloma, vascular lesions, fibro-osseous tumors, pleomorphic adenomas, gliomas, and schwannomas. ${ }^{1-6}$. Moreover, it has been uti-

MANSOURA MEDICAL JOURNAL 
lized in selected cases for management of intermediate and localized malignant tumors. In selected cases, this surgical technique allows the complete removal of the tumor with less morbidity, shorter hospital stay, less blood loss, and lack of an external incision as compared to the traditional techniques. The advantage of the endoscopic approach with respect to the traditional techniques is also a better visualization and magnification of the tumor and its borders and hence, better control of resection margins. The endoscopic approach can be employed together with an external approach whenever there is no possibility of complete visualization and consequent successful resection of the tumor or in those cases of invasion of anatomically inaccessible regions such as the frontal sinus or anterior cranial fossa. The aim of this study is to analyze the author experience in managing sinonasal tumors over a period of 7 years.

\section{PATIENTS AND METHODS}

The study was approved by hospitals ethical committee. Fifty one patients, diagnosed with tumors of the nose and paranasal sinuses and treated by the author between June 1997 and June 2004, at the Otolaryn- gology Department of Mansoura University, Egypt and the ENT Department at Saudi German Hospital, Aseer, Saudi Arabia, were prospectively reviewed (Table 1). All patients received a complete preoperative evaluation as well as a preoperative C $\Gamma$ scan and or MRI imaging. A biopsy was taken preoperatively in most cases not suspected as Juvenile angiofibroma or vascular tumors. All cases of juvenile angiofibroma had also preoperative angiography with embolization 24-48 hours before surgery. Inverting papilloma was staged according to Khafagy et al, $2000^{7}$ (table 2). The decision to either use endoscopic approach alone or to combine it with an external approach depends on the feasibility of either approach to resect the tumor completely. Sometimes this was decided preoperatively depending on the radiological findings. In many cases the decision for use of the combined approach was left to the time of surgery. The nature of the tumor, the tendency for recurrence was explained to the patients and informed consent was taken. The indications for combined approaches include extensive frontal recess and frontal sinus involvement, intracranial invasion. Involvement of the orbit, the septum, sphenoid sinus 
and nasopharynx were not contraindications for endoscopic approach. The maxillary sinus involvement was not a contraindication for endoscopic approach. The middle meatus was widened enough to visualize the tumor. In cases where part of the tumor could not be seen, removal of part of the inferior turbinate and the medial maxillary wall (partial medial maxillectomy) was undertaken. The $45 \mathrm{de}-$ gree endoscope was used to visualize the tumor and it was rotated to look around the corners. In cases where the anterior wall can not be cleaned off the tumor, sublabial approach was used to ensure complete tumor resection. Cases of juvenile angiofibroma were staged according to Andrews and Radkowski 8 staging system (Table 3). Nine cases of juvenile angiofibroma were treated using combined approach using the midfacial degloving approach. The endoscope was utilized primarily to accurately dissect the tumor from the sphenoid, nasopharynx and the pterygopalatine area. In four cases, the endoscope was utilized alone for complete tumor resection. After resection of the lower part of the middle turbinate, a large middle meatal antrostomy was done. The sphenopalatine vessels were clipped or cauterized and the tumor was dissected off the pterygopalatine fossa. The tumor was dissected from all attachment and removed via the nose or the oropharynx.

Results : The patients ages varied between 7 and 65 years (mean, 38 years). Thirty eight of the patients were males $(74.5 \%)$ and 13 were females $(25.5 \%)$. The most common presenting symptoms were nasal obstruction, which was observed in 28 patients $(55 \%)$, epistaxis was observed in 20 cases (39\%). Epistaxis was the presenting symptom in angiofibroma and vascular lesion patients. Facial pain was the presenting symptom in 2 cases. Epiphora was the presenting symptom in a patient with inverting papilloma. Facial swelling was the presenting symptom in a child with fibro-osseous lesion. Follow up period ranges from 8 to 60 months (average 32 months)

Inverting papilloma : 16 cases were treated exclusively endoscopically (Table 2). Combined approaches were utilized in 7 cases; 3 cases were done using sublabial approach, 2 cases were done using osteoplastic frontal flap via brow incision. In one case both sublabial and brow ap- 
proaches were used. In one case craniotomy was used for intracranial extension. In a rare case the tumor was only involving the whole middle turbinate up to the skull base (fig 2). The tumor was removed off the skull base and the attachment was cauterized carefully to avoid break at the skull base. There were two recurrences in the inverting papilloma patients. In one case there was involvement of the anterior and middle cranial fossa, Craniotomy was done using bicoronal flap. Post-operative biopsy revealed foci of malignant areas. Postoperative irradiation follows, this case recurred and the patient dies of recurrent disease. Another recurrence occurred in the frontal recess area after endoscopic approach. This was controlled endoscopically.

Juvenile nasopharyngeal angiofibroma: Thirteen cases were treated (Table 3). Six cases of juvenile nasopharyngeal angiofibroma were done exclusively with the endoscope. One case was recurrent mass (after removal via midfacial degloving approach) involving the palate and the pterygopalatine fossa. The tumor did recur again and was controlled with radiotherapy. The other five cases were exclusively removed with the endoscope, there were no recurrences. In 7 cases a sublabial degloving approach was utilized for tumor excision. The endoscope was used to assure complete tumor removal from the sinuses corners and from the pterygopalatine fossa.

Other tumors : All other tumors were removed completely through endoscopic approach. Two cases of hemangio-pericytoma were encountered. The first case had tumor that was limited to the ethmoids. Preoperative embolization was done 24 hours before the tumor had been endoscopically resected with complete sphenoethmoidectomy. The other case was a 65 years old man, who has severe hepatic cirrhosis with impaired liver function and his prothrombin activity was $40 \%$. He had severely bleeding mass involving the nasal cavity and the anterior ethmoid. Endoscopic excision under local anesthesia was done. There was a significant bleeding during the procedure that required anterior nasal packing. The patient developed pre-hepatic coma for 4 days, then he has improved. The patient died of his hepatic condition 6 months later.

Two cases of osteoma were en- 
countered, In one case, the osteomo was small and it was associated with nasal polyposis. The other osteoma was large involving the ethmoid and nasal cavity encroaching upon the nasal septum, drill was used to downsize the tumor till its attachment can be visualized. Drilling was continued till the site of attachment was separated and the tumor was removed.

Cases of hemangioma were arising from the anterior septum ( 3 cases), the mid and posterior septum (2 case), inferior turbinate (1 case), and anterior ethmoid (1 case). Endoscopic management of nasal hemangiomas was facilitated with bipolar suction coagulation. Two cases required nasal packing.
Two cases of fibro-osseous lesions were encountered. The first case was a 7 years old child. The mass was involving the ethmoid pushing the nasal septum to the lateral nasal wall on other side. It pushes the orbit causing proptosis. The other case was 17 years old; the tumor was involving the ethmoid and obstructing the frontonasal recess. Both cases were removed endoscopically with no difficulty. A 17 years old patient had anterior nasal mass involving the floor of the nose. CT scan showed a tooth in the upper part of the mass (fig 3). The tumor was completely removed endoscopically. There was a missing canine tooth.

The last case was salivary gland tumor arising from the mid septum.

Tablel. Sinonasal tumors treated with endoscopic and endoscopic assisted approaches

\begin{tabular}{|l|l|l|l|}
\hline Sinonasal tumor & Number & $\begin{array}{l}\text { Endoscopic } \\
\text { resection }\end{array}$ & $\begin{array}{l}\text { Combined } \\
\text { approaches }\end{array}$ \\
\hline Inverted papillma & 23 & 16 & 7 \\
\hline $\begin{array}{l}\text { Juvenile } \\
\text { angiofibroma }\end{array}$ & 13 & 6 & 7 \\
\hline Vascular lesions & 7 & 7 & \\
\hline Fibro-oseous lesions & 2 & 2 & \\
\hline Hemangiopericytoma & 2 & 2 & \\
\hline Osteoma & 2 & 2 & \\
\hline $\begin{array}{l}\text { Others (salivary } \\
\text { gland tumors. } \\
\text { odontogenic tumor }\end{array}$ & 2 & 2 & 14 \\
\hline Total & 51 & 37 & \\
\hline
\end{tabular}


Table 2. Staging (Khafagy et al. $2000^{7}$ ). number and approaches used for inverting papiiloma: (No: number. OF: osteoplasic frontal tlap)

\begin{tabular}{|c|c|c|c|c|}
\hline Stage & Description & approach & No & \\
\hline 1 & $\begin{array}{l}\text { Tumors involving the anterior } \\
\text { ethmoid. posterior ethmoid. } \\
\text { sphenoid sinus with or } \\
\text { without involvement of } \\
\text { middle or inferior turbinate }\end{array}$ & endoscopic & 4 & 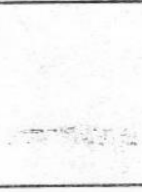 \\
\hline IIA & $\begin{array}{l}\text { A) Tumors involving the } \\
\text { maxillary sinus or any of its } \\
\text { walls. }\end{array}$ & $\begin{array}{l}\text { endoscopic } \\
\text { combined } \\
\text { (sublabial) }\end{array}$ & $\begin{array}{l}10 \\
3\end{array}$ & \\
\hline IIB & $\begin{array}{l}\text { tumors extending to the } \\
\text { frontal sinus or extensive } \\
\text { involvement of the } \\
\text { nasofrontal recess }\end{array}$ & $\begin{array}{l}\text { Combined } \\
(2 \text { OF. I both } \\
\text { sublabial and OF }\end{array}$ & 3 & \\
\hline III & $\begin{array}{l}\text { Bilateral tumors (tumors } \\
\text { involving both sides of the } \\
\text { nasal cavity)invading the } \\
\text { septum or the floor of the } \\
\text { nose }\end{array}$ & endoscopic & 1 & . \\
\hline IV & $\begin{array}{l}\text { Tumors extending outside the } \\
\text { nasal cavity and paranasal } \\
\text { sinuses i.e. the cranial cavity } \\
\text { or the orbit }\end{array}$ & $\begin{array}{l}\text { endoscpoic } \\
\text { combined } \\
\text { (craniofacial) }\end{array}$ & $\begin{array}{l}1 \\
1\end{array}$ & \\
\hline
\end{tabular}

Table 3. Classification (Andrews and Radkowski) ${ }^{8}$ and approaches for juvenile angiofibroma tumor patients.

\begin{tabular}{|l|l|l|l|}
\hline Stage & Description & approach & No. \\
\hline IA & $\begin{array}{l}\text { Limited to nose and nasopharyngeal } \\
\text { area }\end{array}$ & endoscopic & 2 \\
\hline IB & Extension into one or more sinus & endoscopic & 2 \\
\hline IIA & $\begin{array}{l}\text { Minimal extension into } \\
\text { pterygopalatine fossa }\end{array}$ & endoscopic & 2 \\
\hline IIB & $\begin{array}{l}\text { Occupation of the pterygopalatine } \\
\text { fossa without orb:tal erosion }\end{array}$ & $\begin{array}{l}\text { combined } \\
\text { approach }\end{array}$ & 2 \\
\hline IIC & $\begin{array}{l}\text { Infratemporal fossa extension without } \\
\text { cheek or pterygoid plate involvement }\end{array}$ & $\begin{array}{l}\text { combined } \\
\text { approach }\end{array}$ & 3 \\
\hline IIIA & $\begin{array}{l}\text { Erosion of the skull base (middle } \\
\text { cranial fossa or pterygoids) }\end{array}$ & $\begin{array}{l}\text { combined } \\
\text { approach }\end{array}$ & 1 \\
\hline IIIB & $\begin{array}{l}\text { Erosion of skull base with intracranial } \\
\text { extension with or without cavernous } \\
\text { sinus involvement }\end{array}$ & $\begin{array}{l}\text { combined. } \\
\text { approach }\end{array}$ & 1 \\
\hline
\end{tabular}

Vol. 36, No. 3 \& 4 July., \& Oct, 2005 

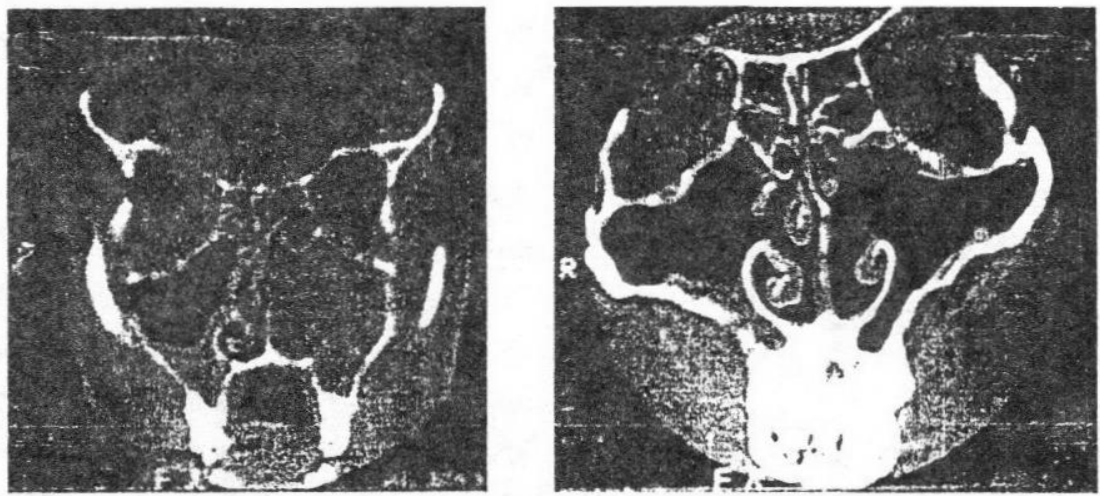

Fig. 1 : Pre and postoperative CT scan of patient with left inverted papilloma

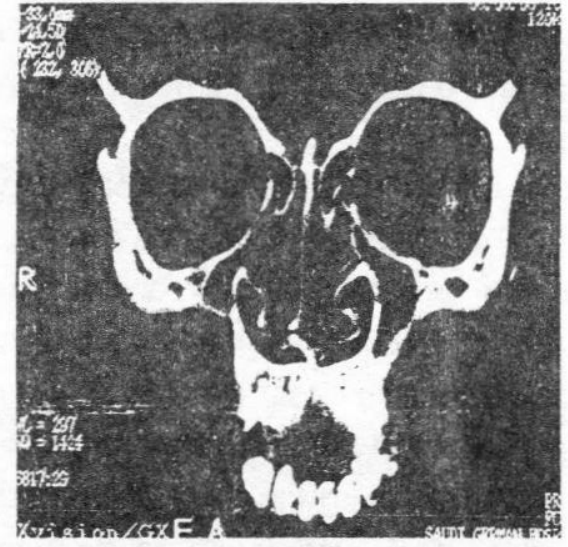

Fig 2 : Patient with inverted papilloma of the right middle turbinate

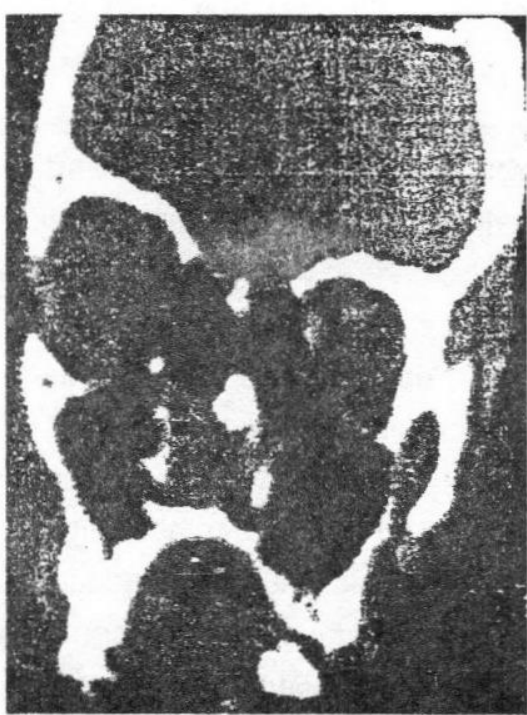

Fig 3 : Patient with odontogenic tumor with teeth in the upper part (arrow).

MANSOURA MEDICAL JOURNAL 


\section{DISCUSSION}

Endonasal endoscopic surgery has been employed successfully in the treatment of rhinosinusitis and is now well accepted. Several reports have shown that benign lesions such as fibro-osseous lesions, vascular tumors, gliomas, schwannomas, and pleomorphic adenomas can be removed by means of endoscopic surgery.

Endoscopes provide excellent illumination and visualization, which facilitates preoperative assessment, operative resection, and postoperative follow-up. 2 It does not only ensure complete removal of the tumor but also avoids unnecessary removal of surrounding sinonasal tissues and external incision with subsequent scarring.

Inverted papilloma : In contrast to prior conservative resections including local excisions and polypectomies that resulted in unacceptable high recurrence rates, current endosccpic techniques enable a more complete yet controlled resection with less patient morbidity. This is supported by recent literature. More radical procedures such as medial maxillectomy, septectomy can be done solely with the nasal endoscope. Also, orbital extension, nasolacrimal duct invasion can be managed endoscopically. Control of sphenopalatine vessels can be carried out endoscopically when needed. Using endoscopic resections of selected inverting papilloma tumors, other authors reported recurrence rates of $0 \%$ to $33 \% \cdot{ }^{9-13}$. The recurrence rate for inverting papilloma cases in this study was $6.8 \%$ supports the endoscopic and endoscope-assisted resection of such tumors.

Improved imaging with $\mathrm{CT}$ and MRI better define the extent of the tumor preoperatively and aid follow-up surveillance. ${ }^{2}$ In many cases, the decision about whether an adjunctive external approach is also required is therefore made at the time of surgery and unless the tumor size is limited, consent for a possible external access is taken. All patients were looking for endoscopic approaches. The use of combined approaches was observed to be less as the surgeon gained more experience with better navigation using the angled 45 endoscope. This was found to be very helpful in cleaning the maxillary sinus and the frontal recess area. Wolfe et al 2 addressed the importance of 
identification of inverting papilloma attachment sites and the meticulous removal of the diseased mucosa including a rim of normal mucosa. This is very helpful in managing maxillary sinus involvement. However, it was found to be difficult to localize the site of attachment of the tumor in the ethmoid and the frontal recess area as well as recurrent tumors. The frontal recess area is a critical area and should be cleaned very meticulously otherwise recurrence would happen.

Juvenile nasopharyngal angiofibroma : Endonasal endoscopic resection of angiofibroma has been reported by many authors 5,14-16. Extensive involvement of the infratemporal fossa, skull base or intracranial extension is considered a contraindication for endoscopic resection of angiofibroma. The endoscope was helpful in dissecting the tumor from the sphenoid, ethmoid, maxillary sinuses, nasopharynx and the pterygopalatine fossa. Preoperative embolization was very helpful in decreasing bleeding and making endoscopic dissection much easier. Our experience with endoscopic management (without external approaches) for this tumor was only limited to 6 cases. Although it is difficult to draw conclusion from this small number, we have found that the endoscopic approach is efficient in management of selected angiofibroma tumors. We are now gaining more experience with endoscopic resection of this tumor which $\mathrm{i}_{3}$ more common in our area (Egypt).

The goal of endoscopic approach, for all sinonasal tumors treated, was complete tumor resection. The low rate of recurrences in this series $(5.8 \%)$ indicates that endoscopic resection is a reliable and should be used whenever it is possible. Hypotensive anesthesia have been very helpful in decreasing the amount of bleeding and hence, better visualization, shortening of operation time and complete tumor resection. Experience with endoscopic sinus surgery and also traditional techniques are important for managing such tumors.

Conclusion : Endoscopic resection of sinonasal tumors is effective. The endoscopic approach can be employed together with non-endoscopic approach whenever there is no possibility of complete visualization and consequent successful endoscopic resection of the tumor. Endoscopic follow up after surgery is very important for detection of early recurrences.

MANSOURA MEDICAL JOURNAL 


\section{REFERENCES}

1. Pasquini, E MD, Sciarretta, V, Frank, G, et al (2004) : Endoscopic treatment of benign tumors of the nose and paranasal sinuses. Otolaryngol Head Neck Surg; 131:180. (Grade B).

2. Wolfe, G. S. (2004) : Schlosser J, R, Bolger, E W. , Lanza, C. $D$, and Kennedy, W D Endoscopic and endoscopeassisted resections of inverted sinonasal papillomas., Otolaryngol Head Neck Surg; 131: 174-9. (Grade B).

3. Schlosser RJ, Mason JC, Gross CW. (2001) : Aggressive endoscopic resection of inverted papilloma: an update. Otolaryngol Head Neck Surg; 125:49-53. (Grade B).

4. Brodish BN, Morgan CE, Sillers MJ. (1999) : Endoscopic resection of fibro-osseous lesions of the paranasal sinuses. Am J Rhinol; 13:111-6. (Grade C)

\section{Carrau RL, Snyderman CH, Kas-}

sam AB, et al. (2001) : Endoscopic and endoscopicassisted surgery for juvenile angiofibroma. Laryngoscope; 111:483-7.(Grade B).

6. Yiotakis I, Dinopoulou D, Ferekidis E, et al. (2001) : Pleomorphic adenoma of the nose. Rhinology; 39:55-7. (Grade C).

7. Khafagy $Y$, Loehrl T, and Toohill R (2000) : Clinical Staging for Invertrd Papilloma of the nose and Paranasal Sinuses. Proceedings of the fourth European Congress of Otolaryngology-Head and Neck Surgery. Berlin May, 13-18, Vol; I, pages: 693-98. (Grade B).

8. Radowski D, McGill T, Healy GB, et al. (1996) Angiofibroma.Changes in staging and treatment. Arch Orolaryngol Head Neck Surg; 122:1229.(Grade B).

9. Waitz G, Wigand ME (1992) : Results of endoscopic sinus surgery for the treatment of 
inverted papillomas. Laryngoscope; (Grade B).

10. Stankiewicz JA, Girgis SJ. (1993) : Endoscopic surgical treatment of nasal and paranasal sinus inverted papilloma. Otolaryngol Head Neck Surg; 109:98895.(Grade B).

11. Sukenik MA, Casiano R. (2000) : Endoscopic medial maxillectomy for inverted papillomas of the paranasal sinuses: value of the intraoperative endoscopic examination. Laryngoscope; 110:39-42. (Grade B).

12. Sham CL, Woo JKS, van Hasselt CA. (1998) : Endoscopic resection of inverted papilloma of the nose and paranasal sinuses. J Laryngol Otol; 112:758-64. (Grade B).
13. Kamel RH. (1995) : Transnasal endoscopic medial maxillectomy in inverted papilloma. Laryngoscope; 105:847-53 (Grade B).

14. Kamel RH (1996): Transnasal endoscopic surgery in juvenile nasopharyngeal angiofibroma. J Laryngol Otol; 110: 962-968. (Grade C).

15. Schick B, El Rahman EI Tahan A, Brors D, et al (1999) : Experiences with endonasal surgery in angiofibroma. Rhinology; 37:80-85, (Grade B) .

16. Newlands SD, Weymuller EA (1999) : Endoscopic treatment of juvenile nasopharyngeal angiofibroma. Am J Rhinol; 13:213-219.(Grade B). 


\section{استخدام المناظير الضوثية فيى معالجة \\ أورام الأنف والجيوب الأنفية \\ د. دياسر ووفيق خفاجى}

أستاذ مساعد الأذن والأنف والحنجرة - كلية الطب - جامعة المنصورة

\section{الملاخص العـربى}

تهدف هذه الدراسة إلى تقييم نتائج جراحات المناظير فى علاج أورام الأنف والجيوب الأنفية، وقـــ أجـريت هذه الدراسـة المستـقبليـة على اه مـريض باورام الأنف والجيـوب الأنفيـة والذين تم علاجهم فى الفترة من 199V وحتى ع . بrم وقد استـصلت الأورام إما باستخدام المناظير كلية أو باستخدام المنظار مع الطرق الجراحية الأخرى. وقد اشتملت هذه الدراسة على عدد (rr) مريضاً بالورم الحليمى المقلوب و (rr ) مريضاً بالورم الدموى الليفى واليفعان والأورام الدموية (V) مرضى والأورام العظمية الليفية (r) مرضى والأورام العظمية (ץ) مـرضى وأورام دمـوية اخـرى (ץ) مـرضى وأورام فكية مـريض واحس وأورام غدة لعابية مريض واحد.

كانت متوسط مدة المتابعة أثنين وثلاثين شهراً وقد ارتدت الأورام فى ثلاث حـالات (حالتين ورم حليمى مقلوب وحالة ورم ليفى دموى) ولم تكن هناك مضاعفات كبرى بعد اجراء الجراحة. وقد أعتـــد استخـدام الضرق الجراحية التقليدية مع المناظيـر على مدىى إنتشـار الورم كمـا يلاحظ بالأثعة المقطعية وأشعة الرنين المغناطيسى بالإضافة إلى الملاحظات أثناء الجراحة وقدرة الجراح على رؤية الورم بصورة كاملة. وقد توصلت هذه الدراسة إلى فاعلية جراحة مناظير الجيوب الأنفية (وحدها أو مع الطرق الجراحيـة الأخرى) فى استـــصال أورام الأنف والجيـوب الأنفية وينصح بـاستخـدام المنـاظير مع الطرق التقليدية عند تعذر الرؤية الكاملة للورم ويالتالى الاستنصال الكامل للورم. 